\title{
Truth, History and Myth in Gabriel García Márquez's One Hundred Years of Solitude
}

\author{
Rodica Grigore ${ }^{1}$
}

This essay has as one of its main purposes an analysis of Gabriel García Márquez's masterpiece, the novel One Hundred Years of Solitude (1967) regarded as the fictional space where the notions of truth, history and myth come together and get new meanings. Thus the Colombian writer reshapes, beyond Faulkner's or Borges' influence, not only the Latin American literary tradition of the "Boom", but also finds the perfect pattern for his work in Cervantes' Don Quixote as far as literary truth and the new kind of relationship between reality and fiction are concerned. Thus, the reader of One Hundred Years of Solitude is made, in turn, all-believing and alldoubting, both faithful and skeptical by this novel's fidelities to historical truth (or to any truth) and skepticisms, nothing else, in fact, then the perfect inheritor of Cervantes' knight's last will. And the most convincing evidence that, in its own way, One Hundred Years of Solitude addresses the delicate problems related to truth, but a very specific one: the truth of literature. [Article copies available for a fee from The Transformative Studies Institute. E-mail address: journal@transformativestudies.org Website: http://www.transformativestudies.org (02013 by The Transformative Studies Institute. All rights reserved.]

KEYWORDS: Truth, Myth, History, Modernism, Postmodernism, Literary Tradition.

\footnotetext{
${ }^{1}$ Dr. Rodica Grigore is senior-lecturer in Comparative Literature at "Lucian Blaga" University of Sibiu, Romania. She is the author of three critcal studies: Despre cărţi şi alţi demoni [Of Books and Other Demons], 2002 and Retorica măşstilor în proza interbelică românească [The Rhetoric of Masks in Romanian Modern Fiction], 2005 and Lecturi in labirint [Readings in the Labyrinth], 2007. She has also translated into Romanian the essays of Octavio Paz, Copiii mlasstinii [Children of the Mire], 2003, the poems of the Colombian writer Manuel Cortés Castañeda, Oglinda celuilalt [The Mirrored Other], 2006 and a collection of novellas and short stories of the American writer Andrei Codrescu, Un bar din Brooklyn [A Bar in Brooklyn], 2006. Since 2005 she has been coordinating the anthologies of The International Theatre Festival of Sibiu, Semne [Signs, 2005], Impreună [Together, 2006], Next [2007], Energii [Energies, 2008], InOvaţii [InOvations, 2009]. She has published numerous essays and critical studies especially on modern literature in several Romanian literary magazines: Cultura, Contemporanul, Euphorion, Saeculum, Scrisul Românesc, Viaţa Românească. Recently she has authored a short anthology of Romanian poetry published in Mexico, Spain and Venezuela. Address correspondence to: Rodica Grigore; e-mail: rodica.grigore@gmail.com.
} 